\title{
Assessment of Socio-Economic Impacts of the December 2011 Flood Event in Dar es Salaam, Tanzania
}

\author{
Doreen M. Anande ${ }^{1,2^{*}}$, Philbert M. Luhunga ${ }^{3}$ \\ ${ }^{1}$ Numerical Weather Prediction (NWP) Section, Tanzania Meteorological Agency, Dar es Salaam, Tanzania \\ ${ }^{2}$ Hankuk University of Foreign Studies (HUFS), Seoul, South Korea \\ ${ }^{3}$ Research Section, Tanzania Meteorological Agency, Dar es Salaam, Tanzania \\ Email: ^doreenmwara@gmail.com
}

How to cite this paper: Anande, D.M. and Luhunga, P.M. (2019) Assessment of Socio-Economic Impacts of the December 2011 Flood Event in Dar es Salaam, Tanzania. Atmospheric and Climate Sciences, 9, 421-437. https://doi.org/10.4236/acs.2019.93029

Received: May 22, 2019

Accepted: July 20, 2019

Published: July 23, 2019

Copyright ( 2019 by author(s) and Scientific Research Publishing Inc. This work is licensed under the Creative Commons Attribution International License (CC BY 4.0).

http://creativecommons.org/licenses/by/4.0/ cc) (i) Open Access

\begin{abstract}
Floods are the most devastating hazards that have significant adverse impacts on people and their livelihoods. Their impacts can be reduced by investing on: 1) improving the forecasting skills of extreme and heavy rainfall events, 2) development of Impacts Based Flood Early Warning System (IBFEWS) and 3) effective communication of impacts from anticipated extreme or heavy rainfall event. The development of IBFEWS however, requires a complete understanding of factors that relates to the formation of extreme or heavy rainfall events and their associated socio-economic impacts. This information is crucial in the development of Impacts Based Flood Forecasting Models (IBFFMs). In this study, we assess the socio-economic impacts of the December 2011 flood event in Dar es Salaam as the preliminary stage in the development of IBFFMs for the City of Dar es Salaam. Data from household survey collected using systematic random sampling techniques and structured questionnaires are used. The survey was conducted to acquire respondent's views on the causes of floods impacts, adaptive capacity to extreme or heavy rainfall events and adaptation options to minimize flood impact. It is found that the main causes of floods were river overflow due to heavy rainfall and blocked drainage system. Poor infrastructure such as drainage and sewage systems, and ocean surge were identified to be the causes of observed impacts of the December 2011 flood event in Dar es Salaam. Death cases analysis showed that 43 people were reported dead. The flood event damaged properties worth of 7.5 million Tanzania shillings. Furthermore, the Tanzania Government spent a total amount of $\mathbf{1 . 8 3}$ billion Tanzanian shillings to rescue and relocate vulnerable communities that lived-in low-lying areas of Jagwani to high ground areas of Mabwepande in Kinondoni district.
\end{abstract}




\section{Keywords}

Extreme Rainfall, Impacts Based Flood Forecasting Models (IBFFMs), Socio

Economic Impacts, Impact Based Flood Early Warning System (IBFEWS)

\section{Introduction}

Floods are the most devastating hazards that have potential to cause damage to natural environment, displacement of people, destruction of infrastructure: buildings, roads, railways, bridges and power transmission lines [1]-[6]. The severity of flood impacts however, depends on a number of factors such as geographic location, topography, soil types of the area, increased human settlements and economic assets in floodplains, and reduction of the natural water retention by increased land use change [7] [8].

In recent years, due to population growth, rapid urbanization and climate change, the frequency and intensity of flood events have increased in different regions of the world. These events have posed major humanitarian concern and threaten the efforts of achieving sustainable development and the Millennium Development Goals [9] [10] [11] [12].

Several studies [13] [14] [15] indicated that, the intensity and frequency of flood events will continue to increase in future climate and their impacts are projected to severely compromise socio-economic development particularly in developing countries [16]. Adaptation is a key and only strategy to reduce the impacts of flood events.

However, before the development of adaptation strategies to floods risks, it is important to improve the forecasting skills of heavy rainfall events and develop the Impacts Based Flood Early Warning System (IBFEWS) for anticipated heavy rainfall events. This is important for effective flood risk management strategies to minimize the negative impacts of floods. The development of IBFEWS however depends on clear understanding of factors associated with a particular flood event and the associated socio-economic impacts of such event. This information is important in the development of Impacts Based Flood Forecasting Models (IBFFMs). In this study, we assess the socio-economic impacts of the December 2011 flood in Dar es Salaam as the preliminary stage in the development of IBFFMs.

\section{Data and Methodology}

\subsection{Geography}

The city of Dar es Salaam is located between latitudes $6.36^{\circ} \mathrm{S}$ and $7^{\circ} \mathrm{S}$ and between longitudes $33.33^{\circ} \mathrm{S}$ and $39^{\circ} \mathrm{E}$, at an altitude of $53 \mathrm{~m}$ above the sea level (Figure 1). The city is found along coastline of western Indian Ocean and has tropical type of climate modulated by the warm tropical Indian Ocean. Dar es Salaam experience two distinct seasonal rainfall-the short rainfall season ( $V u l i)$ 


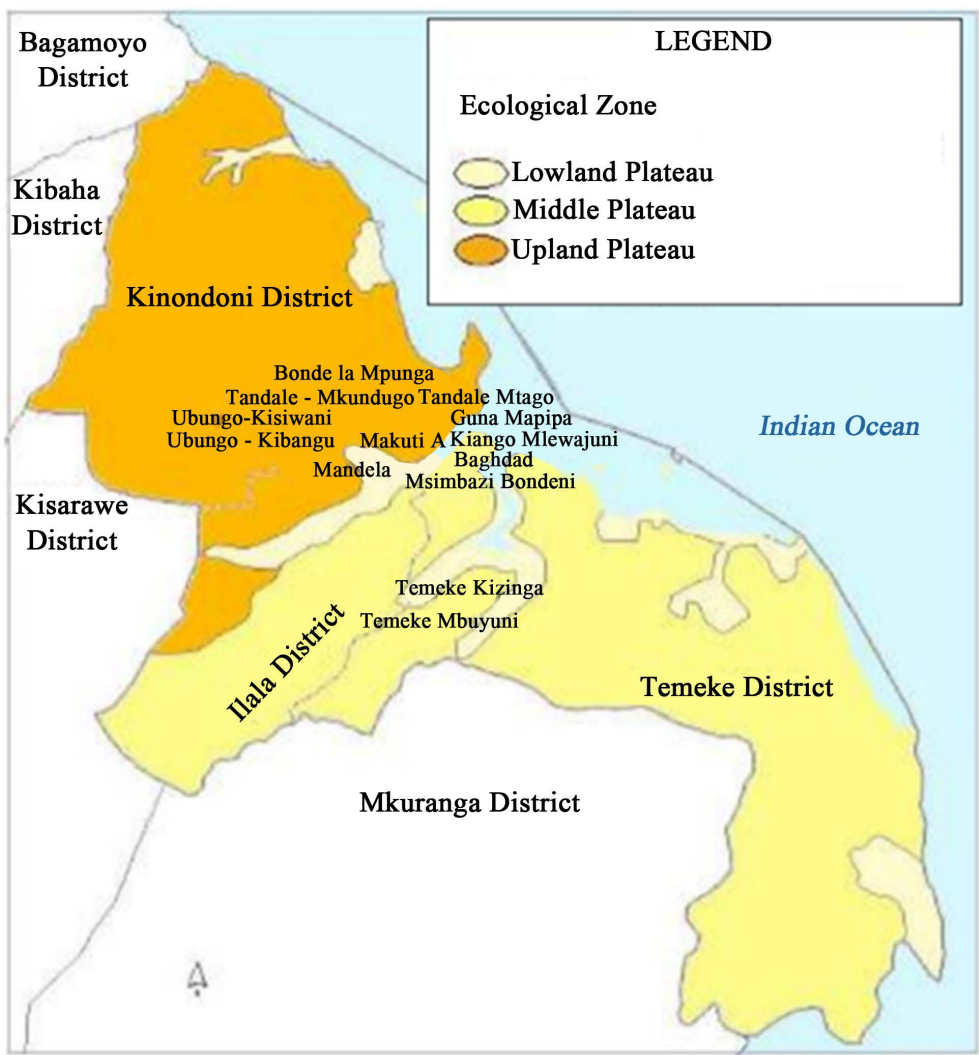

(a)

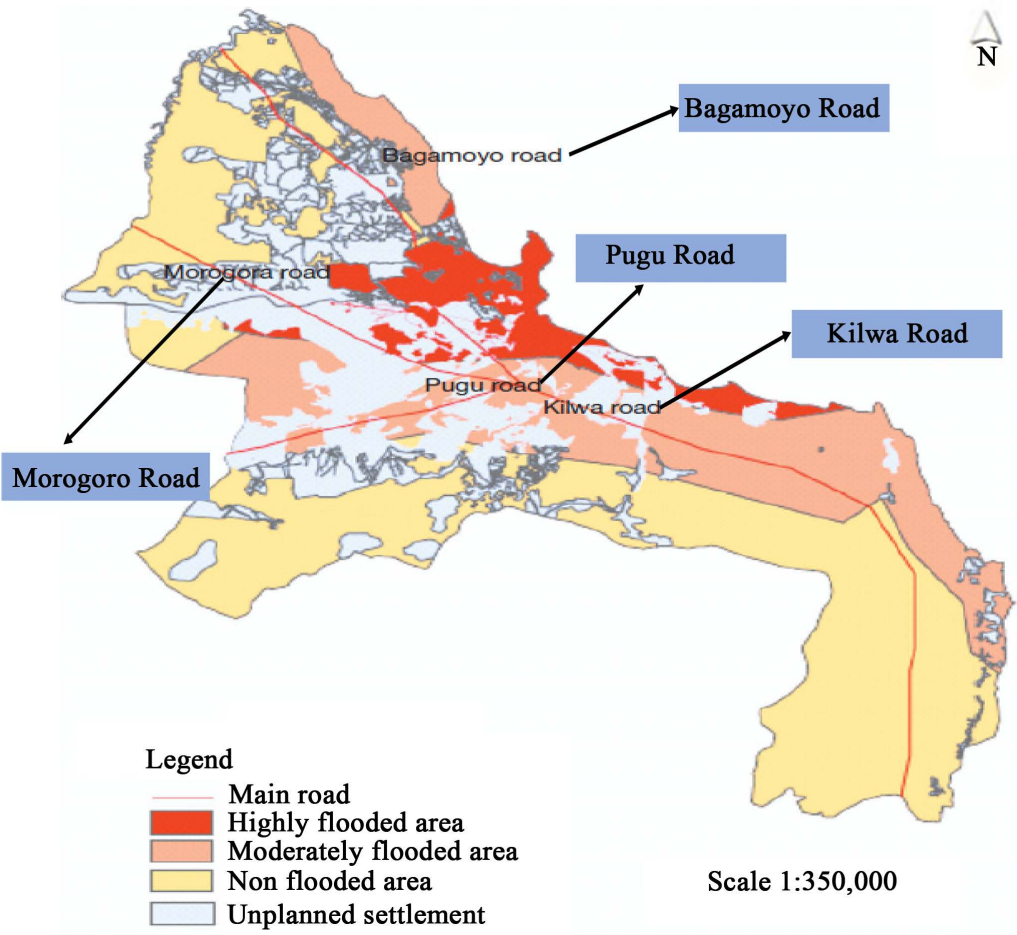

(b)

Figure 1. Map of Dar es Salaam indicating flood hazard zone adopted from [17]. (a) Map of Dar es Salaam municipal districts; (b) Flood hazard zone map overlain on urban poor settlements. 
that starts in October and continues through December (OND) and the long rain season (Masika) that starts in March and continues through May (MAM). These rainfall seasons are mainly attributed by the movement of the Inter Tropical Convergence zone (ITCZ) which moves southwards in October and reaches the southern part of the country in January or February and reverses Northwards in March, April and May. The seasonal rainfall over Dar es Salaam varies in space and time. The variation is higher during short rains ( Vuli) than the long rains (Masika) seasons. The amount of rainfall usually ranges from $66 \mathrm{~mm}$ to $116 \mathrm{~mm}$ (in Vuli) and $136 \mathrm{~mm}$ to $253 \mathrm{~mm}$ in (Masika) seasons and the annual rainfall over Dar es Salaam is $1146.8 \mathrm{~mm}$ (Figure 2).

Dar es Salaam is a business city in Tanzania, it contains high concentrations of trade industries and manufacturing companies. However, due to increased incidences of extreme weather events the city has become vulnerable to floods events. This vulnerability is attributed by poor planning of settlements about $70 \%$ of settlements are unplanned. The other factors that increase vulnerability of communities to flood events includes, lack of infrastructure (e.g., poor storm water drainage systems) and rural-urban migration that increased the population and accelerated urbanization. Most of residents use pit latrines, which are usually poorly constructed and badly maintained. The pit latrines are found in high density areas and are subject to flooding during the rainy season because they lack drainage channels, especially in squatter zones.

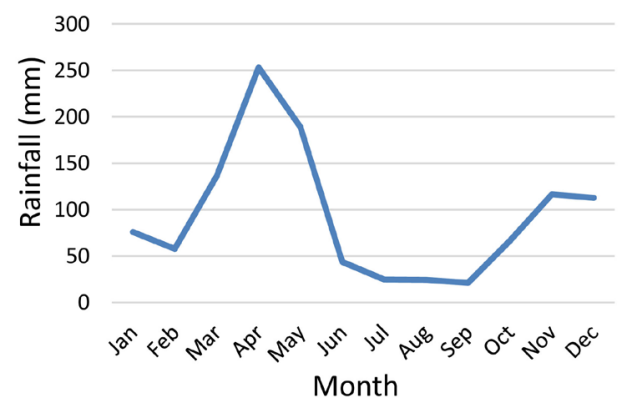

(a)

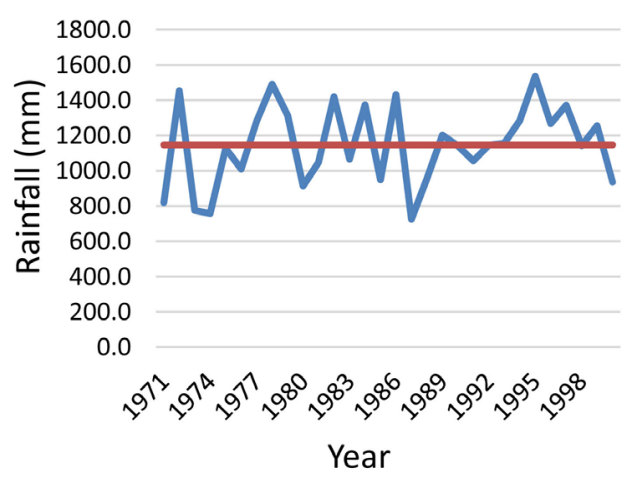

(a)

Figure 2. Annual and inter-annual cycles of rainfall over Dar es Salaam. (a) Annual cycle calculated by averaged monthly rainfall total from 1971-2000; (b) Inter-annual variability of rainfall from 1971-2000. 
Generally, the city of Dar es Salaam is divided into three ecological zones, namely the upland zone comprising hilly areas to the west and north of the City, the middle plateau, and the lowlands, which include Msimbazi Valley, Jangwani, Mtoni, Africana and Ununio areas. Coastal degradation and salt-water intrusion are major problems for Dar es Salaam's coastal areas today, and under projected climate change and possible sea level rise, coastal ecosystems would be highly threatened [18]. The livelihoods and ecosystems services of coastal communities are projected to be compromised in future. Residents of coastal wetlands such as Suna, Mtoni Azimio, Msasani Bonde la Mpunga faces saltwater intrusion.

\subsection{Data}

This study uses primary data of socio-economic implication of the flood event over the city of Dar es Salaam. These data include loss and damage posed by the flood and the cost incurred by the Government of Tanzania to relocate communities from low laying areas of Jagwani to high ground areas of Mabwepande. These data were obtained from the Disaster Management Department of the Prime Minister's Office in Tanzania. Other primary data were obtained from house hold survey conducted within the study region. The survey was specifically conducted to people displaced from their area of residence due to flood to other places including Mabwepande re-settlement area. The survey was conducted to obtain information from respondent's views about the impacts of the 2011 flood event, what were the causes of such flood event, adaptive capacity to extreme events and adaptation options to minimize flood impact on human lives.

\subsection{Methodology}

Primary data were collected through personal interview using a structured questionnaire written in English, translated into Swahili and administered in Swahili. It is important to note that before implementation of the main data collection from the sampled households, the structured questionnaire was subjected to pre-testing on a randomly selected sample of 59 households displaced to Mabwepande. The pre-testing of the questionnaire intended to: 1) assess the time needed to conduct the household survey; 2) assess whether the designed questions can be understood by the respondents and testing the effects of question formulation (appropriateness of questions in terms of socio-cultural standard, lifestyles, etc.).

After conducting the pre-testing of the structured questionnaire, expert meeting of interviewers was conducted to analyze the tested questionnaire and to have common understanding of each question in the structured questionnaire. This meeting resulted into modification of the questionnaire by adding some question in order to acquire more information and irrelevant questions were removed from the structured questionnaire. The modified questionnaire was used in this study to collect primary data. 


\subsubsection{Sampling Techniques}

The sampling unit for this study was a household. The study aimed at completing a total of 59 Households questionnaires to obtain sufficient information to draw valid conclusions from the sample for the population of interest. Of the total sampled, were females and males head of household. Accordingly, a sample of households selected was proportionate to the number of households in the area. Thus, the number of households interviewed/questionnaires analyzed was 59 (out of 500) which represents 11.8 per cent of the total population size. This percentage has been used in other studies such as [19].

\subsubsection{Data Collection Techniques}

Data collection in the household's surveys was carried out through face-to-face interviews using a structured questionnaire consisting of both closed and open-ended questions formulated to capture information in the three areas of major focus of the study: (causes of flood, impacts, adaption option).

Systematic random sampling technique was used to draw respondents from affected community. This was done by using a registered book of all household given a piece of land at Mabwepande. A size of population of households was 500. This study aimed to sample $10 \%$ of the entire population for meaningful analysis. One household was drawn in every 10 households, making a total number of 59 households ( $11.8 \%$ out of 500 ).

The interviews were conducted by two people (one man and one lady) who were recruited based on several criteria, including previous experience in data collection and educational backgrounds. The objective of the survey was made clear to the respondent through a consent seeking statement, which was read out at the first contact with each respondent. The interviews were conducted in Swahili, thus the interview technique adopted in the survey was to read the questions as verbally as possible. Likewise, attempts were made to persuade the respondent who, for various reasons, was unwilling to be interviewed. No replacements of either unavailable or unwilling respondents were made. Data collection took place in one day (14 February 2011) and yielded a sample of 59 completed questionnaires.

More resources and a larger sample size may be necessary to study a large population than to study a small population. Due to lack of enough resources such as costs of conducting the whole exercise, the amount of time needed to collect the study's data and management issues result to the sample size of 59 households.

Moreover, the qualitative data obtained were coded, edited and entered in a computer and the IBM Statistical Package for Social Science (SPSS) software version 2.0 spread sheet was used for the analysis. Descriptive statistics were run to give frequencies and then cross-tabulation was undertaken. Multiple response questions were analyzed so as to give frequencies and percentages. Tables, pie and bar charts were used to present different variables. Cross-tabulation allowed a comparison of different study parameters. 


\section{Results and Discussion}

\subsection{Explanation of the Rainfall Events}

From $19^{\text {th }}$ to $22^{\text {nd }}$ December 2011, the city of Dar es Salaam experienced heavy rainfall event that triggered worst flooding in various parts especially over low laying areas of Msimbazi valley or wet land. The flooding events resulted into major socio-economic implications including the death of forty-three people. The city major transportation networks were destroyed by the floods. Some bridges were completely swept out and others were covered with water.

Climatologically, heavy rainfall events over northeastern part of Tanzania, particularly over the city of Dar es Salaam during October, November, December (OND) seasons are influenced by strong Ocean-Atmosphere interactions in the Equatorial Pacific Ocean and in the Northern Part of Tropical Indian Ocean. These interactions include the El Niño Southern Oscillation (ENSO) and Indian Ocean Dipole (IOD). The years (1961, 1982, 1997, and 2006) where the Equatorial Pacific and Indian Oceans experienced El Niño and positive IOD phase respectively were associated with heavy rainfall events over northern part of Tanzania in general and over Dar es Salaam in particular [20] [21] [22] [23].

The stream line analysis indicates that the climatology of stream line during OND season is dominated by the northeasterly wind flows that travel parallel to coastline of Somali. During positive phase of IOD and El Niño year, the north easterly winds flow drags lot of moisture from the Ocean to the Continent (Figure 3).

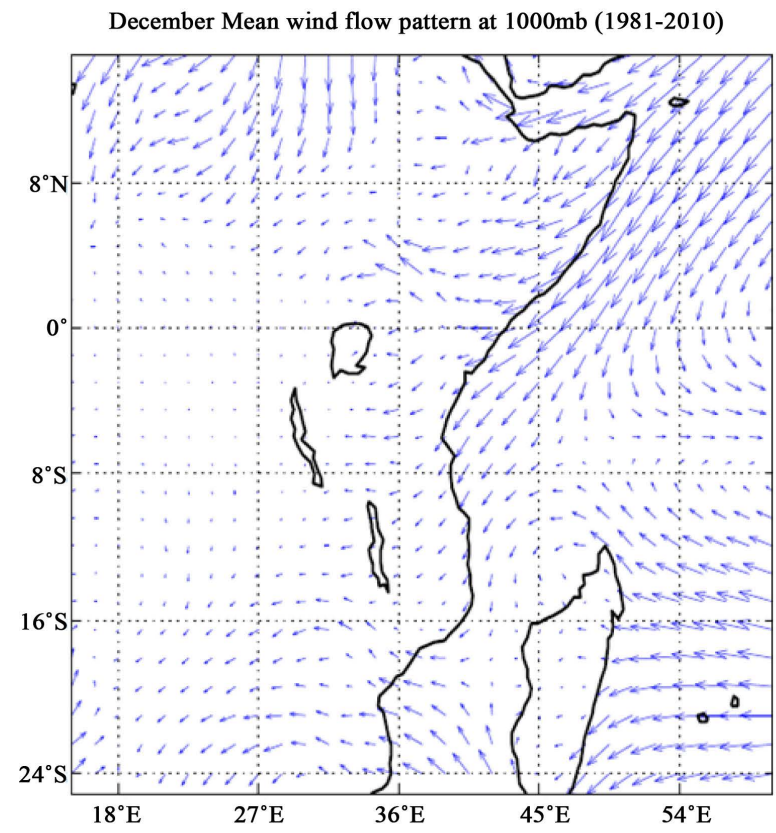

(a)

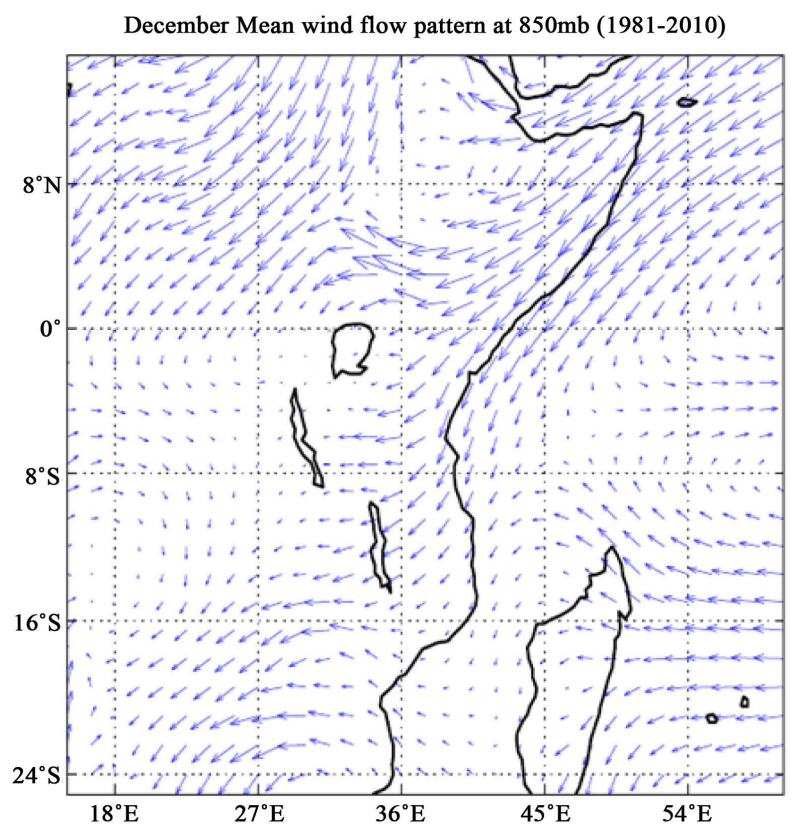

(b)

Figure 3. Climatology of the stream lines during OND seasons averaged from 1981-2010 over the Eastern, Northern, Southern and over the horn of Africa. (a) Climatology of the stream line from 1981-2010 at $1000 \mathrm{hPa}$; (b) Climatology of the stream line from 1981-2010 at $850 \mathrm{hPa}$. 
The stream line analysis during December 2011 heavy rainfall events indicates that the dominant flow of wind were north easterlies towards the East Africa coastline and due to land and ocean temperature contrast, the convection process became enhanced along the Coastline. Figure 4 indicate that in the north-western part of the Indian Ocean was development of trough like structure. This also enhanced convection over Dar es Salaam. In general, the heavy

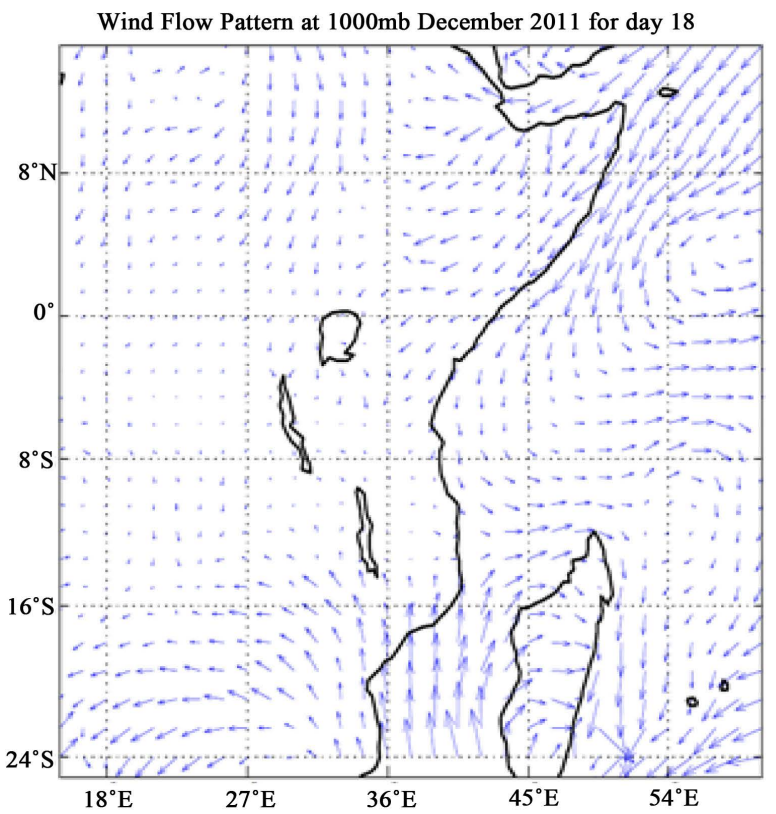

(a)

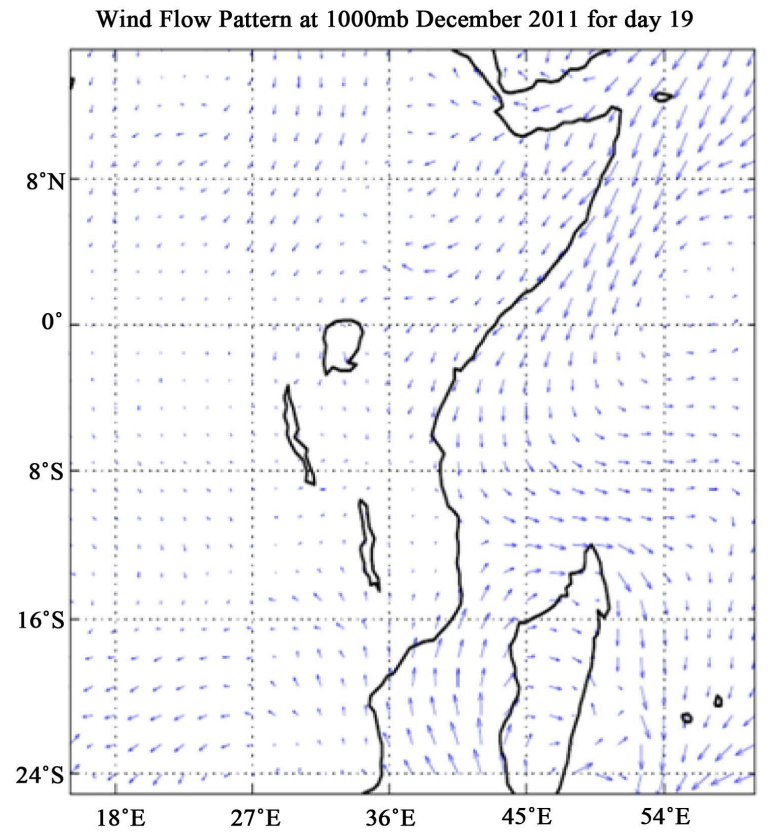

(c)

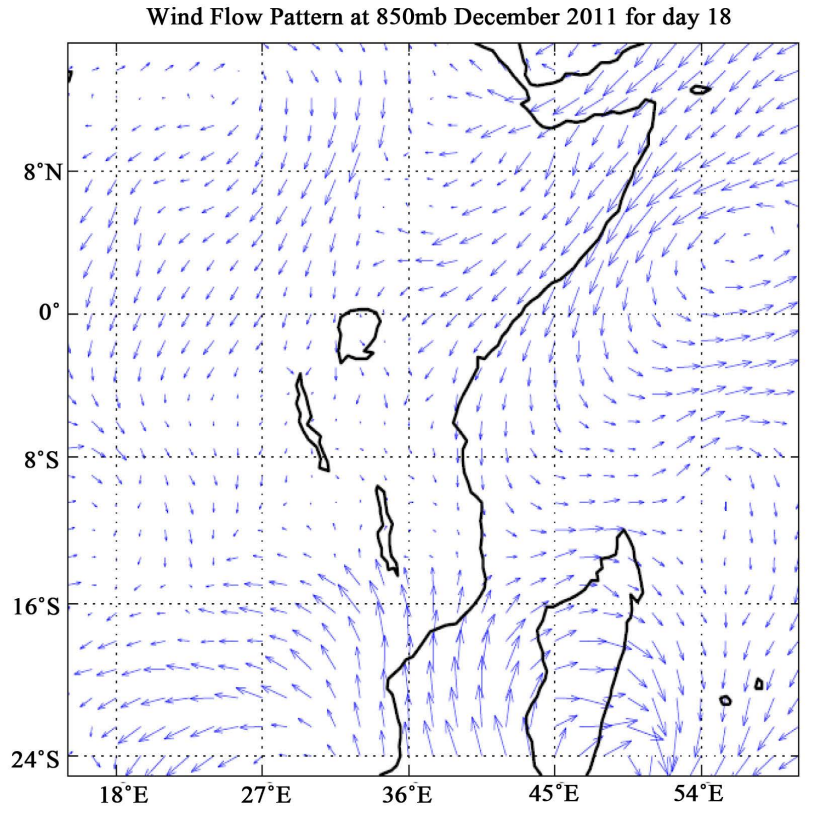

(b)

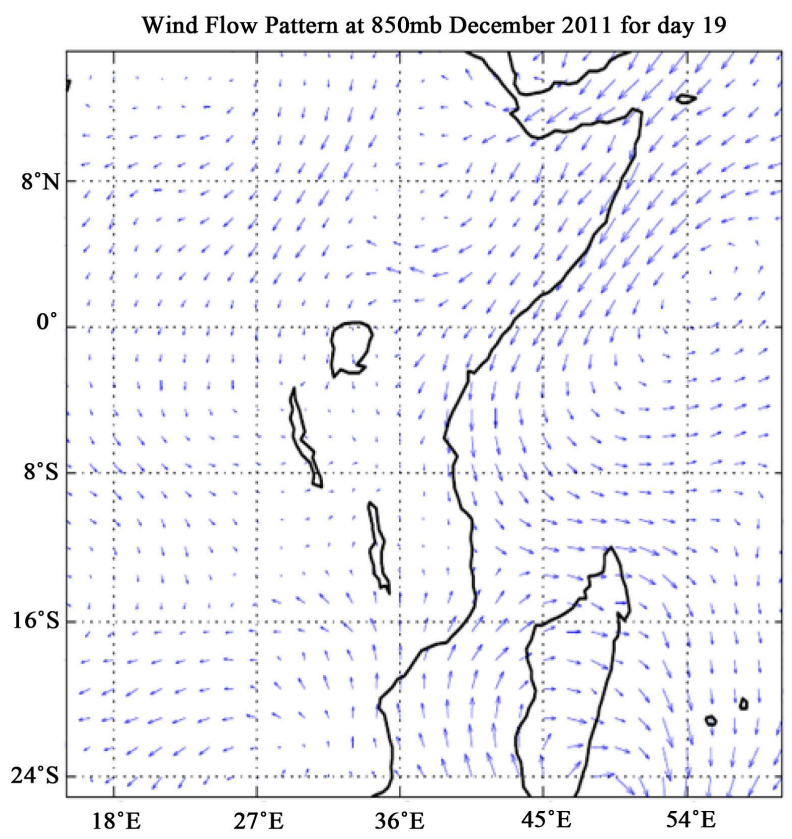

(d)

Figure 4. Climatology of the stream lines from $18^{\text {th }}$ to $19^{\text {th }}$ of December 2011 over the Eastern, Northern, Southern and over the horn of Africa. (a) Stream line at $1000 \mathrm{hPa}$ on $18^{\text {th }}$ December, 2011; (b) Stream line at $850 \mathrm{hPa}$ on 18th December, 2011; (c) Stream line at $1000 \mathrm{hPa}$ on 19th December, 2011; (d) Stream line at $850 \mathrm{hPa}$ on 19th December, 2011. 
rainfall that occurred over Dar es Salaam was influenced by the convection activities along the East Africa Coastline, enhanced by low pressure areas developed in the North-western part of Indian Ocean and south western part of Madagascar.

The sea surface temperature maps (not presented here) indicated that there was strong warming over the Eastern, North and Northwestern Australia. The prevailed surface Westerly wind pushed warm surface water from topical Pacific Ocean towards western Indian Ocean. This warm surface water spread around western equatorial Indian Ocean coupled with significant warming developed over western Indian Ocean (coast of Dar es Salaam) on 18-21 December enhanced more convection along the coastal regions.

\subsection{The Major Factors That Led to Flood in December 2011}

Results from the survey indicate that the flood in December 2011 over the city of Dar es Salaam was mainly caused by river overflow due to heavy rainfall and blocked drainage system. But there was also a group of people who did not know the cause of the flood (Figure 5). Other respondent indicated that the flood was attributed by poor infrastructure such as drainage and sewage systems, living in low land areas, and ocean surge.

Since the survey were conducted to Mabwepande where affected communities where taken after the government order to displace all communities living in the low laying areas, one of the questions in the questionnaire was to ask the respondents their previous location before floods. Results indicate that most of the affected communities came from Magomeni mapipa, Suna and Hannanasif areas, see Table 1 below.

Table 1. Previous location of respondents.

\begin{tabular}{ccc}
\hline Location where respondent lived before the flood & Frequency & Percent \\
\hline Hannanasif & 8 & 13.6 \\
Gongo la mboto & 2 & 3.4 \\
Jangwani & 6 & 10.2 \\
Kigogo & 6 & 10.2 \\
Kinondoni Moscow & 3 & 5.1 \\
Kinyerezi & 1 & 1.7 \\
Magomeni mapipa, suna & 22 & 37.3 \\
Mbagala & 1 & 1.7 \\
Mchikichini & 3 & 5.1 \\
Msimbazi bondeni & 2 & 3.4 \\
Mwembechai & 1 & 1.7 \\
Tabata & 2 & 3.4 \\
Total & 57 & 96.6 \\
No response & 2 & 3.4 \\
Total & 59 & 100.0 \\
\hline
\end{tabular}



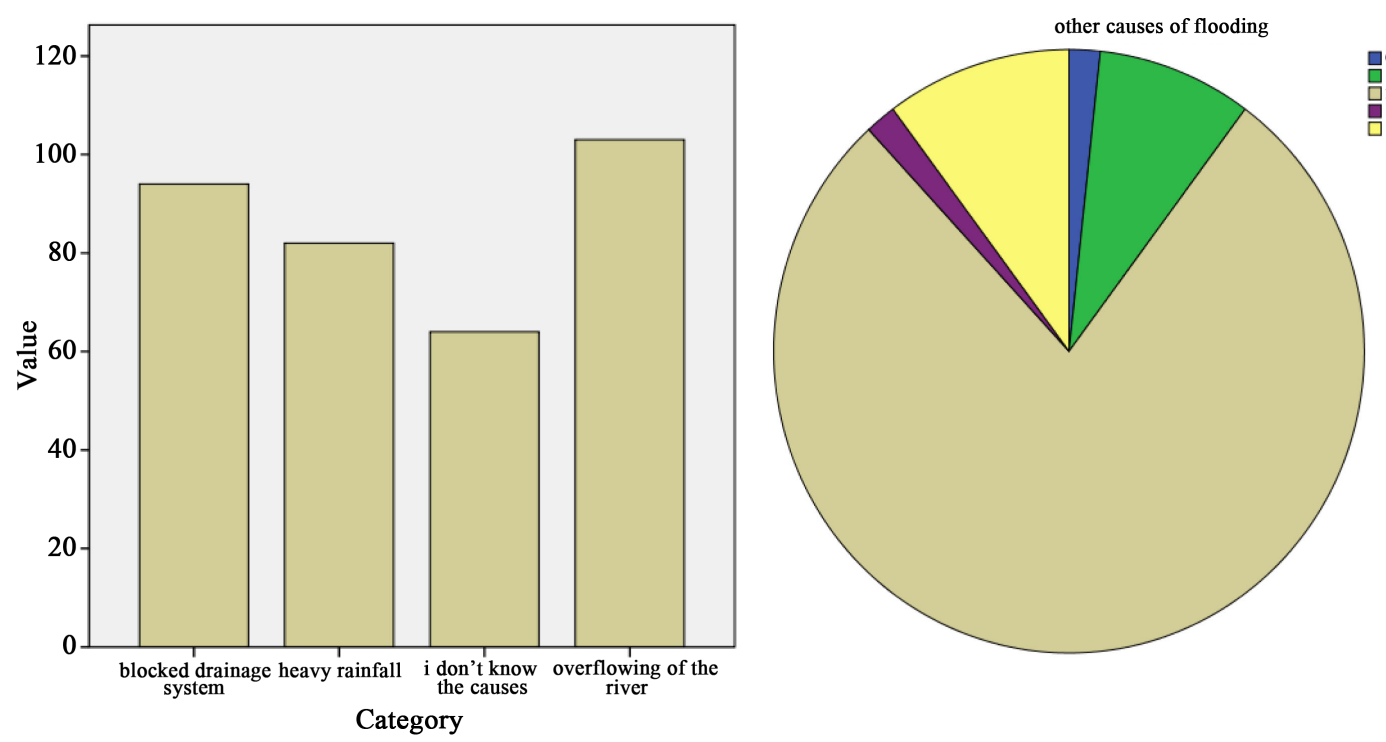

God punishiment living in low land area rocean surge ocean surge

Figure 5. Factor contributed to the flood of December 2011 in the city of Dar es Salaam.

Based on the analysis from the survey it indicates that rainfall is not the only source of flood over the city of Dar es Salaam, other factors such as the topography and infrastructures can lead to flood events. All areas indicated in Table 1 above are flood prone due to fact that is at the low altitude from the sea level. In these areas there is small rivers pass through and discharge water to the Indian Ocean. Therefore, if there is rainfall due to poor infrastructure the rivers overflow and results to floods. However, the areas that are close to the Indian Ocean Coastline experience floods due to rise of sea level which results to ocean surge. This was identified by respondents to be among of the cause of flooding in those areas. The findings from this study correspond to what [24] found after analysing Dar es Salaam's vulnerability to sea level rise. They estimate that at present $8 \%$ of the city currently lies in a low elevation zone below the 10 -meter contour line.

Studies by [25], identified the flood prone areas in Dar es Salaam to include Msasani bonde la mpunga. This area has mixed residential, commercial and institutional settlements; and has the fastest growing settlements in Kinondoni municipality. Other areas include Msimbazi valley, Jangwani. This is a slum area characterized by floods during rainy season almost every year.

Areas such as (Magomeni Mapipa, Jangwani Valley adjacent Muhimbili and Hannanasif) are found in Kinondoni district and have an informal settlement. These areas are located in low altitude from the sea level therefore, communities living in those areas suffers flooding during the rainy season nearly every year. The Msimbazi river, joined by the Ubungo river which flows across Tandale Mkunduge and Mtogole influence flooding event over low laying area during heavy rainfall events. It is important to note that the Ubungo River which is baptized as Ng'ombe River, literally meaning "Cow Dung Carrying River" and the Msimbazi river influence flooding events over Jangwani areas (respondent's location before evacuate). 
Msimbazi Valley (Msimbazi Bondeni down) has Msimbazi River system found in Ilala district. The valley covers a wide area across both the Ilala and Kinondoni Municipalities. The area is known to flood even during the absence of rainfall in Dar es Salaam, due to Msimbazi River, as it flows through Ilala and Kinondoni on its way to the sea, routinely encounters clogged drains and structural interferences along its course and influence floods.

\subsection{Impact of December 2011 Floods on Social-Economic Activities}

\subsubsection{Source of Livelihood}

The communities living in flood prone areas to a large extent are marginalized and characterized by inadequate adaptive capacity to respond to impacts. Socio-economic analysis of the flood victims showed that the majority, especially women, depend on small scale business as the main source of income (Figure 6).

During the survey most of women and men did not have work due to the effect of the displacement and because they lost most of the resources they had before the flood. Few respondents had small business in the area where they have been allocated after displacement because the area is far away from town city and the development of the area is still in low conditions resulting in every individual seeking for small amount of income for survival of their families. There are no good facilities such as transport for easy trade of goods from one place to another and these results to community living there depend only on small income getting from small businesses which have least cost compared to larger businesses which requires high financial capacity in coordination. Most of these small businesses involve use of their own hands to make some goods and sell to the surround community such as food stuffs especially for women and most of other women they remained housewives. For agriculture case is specifically for domestic purpose of getting food for survival for the family hence there

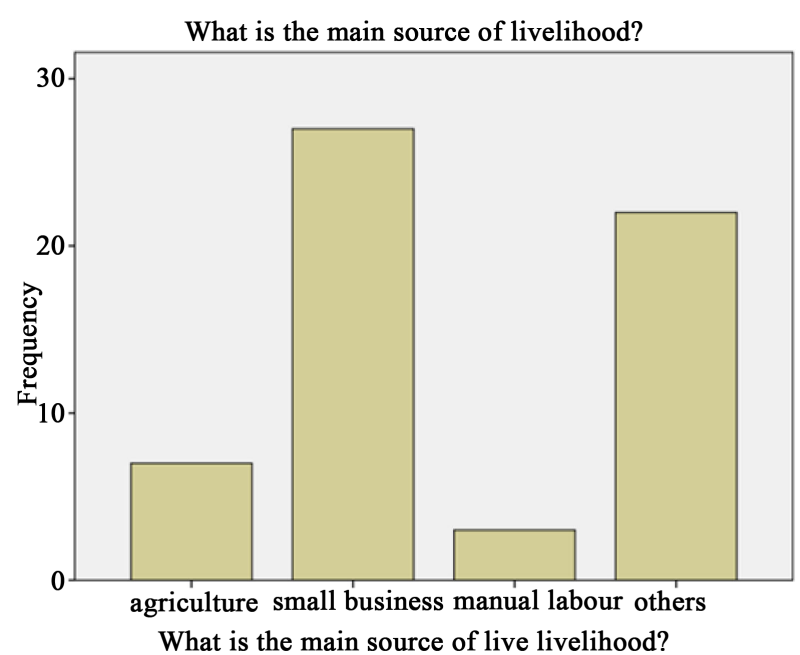

(a)

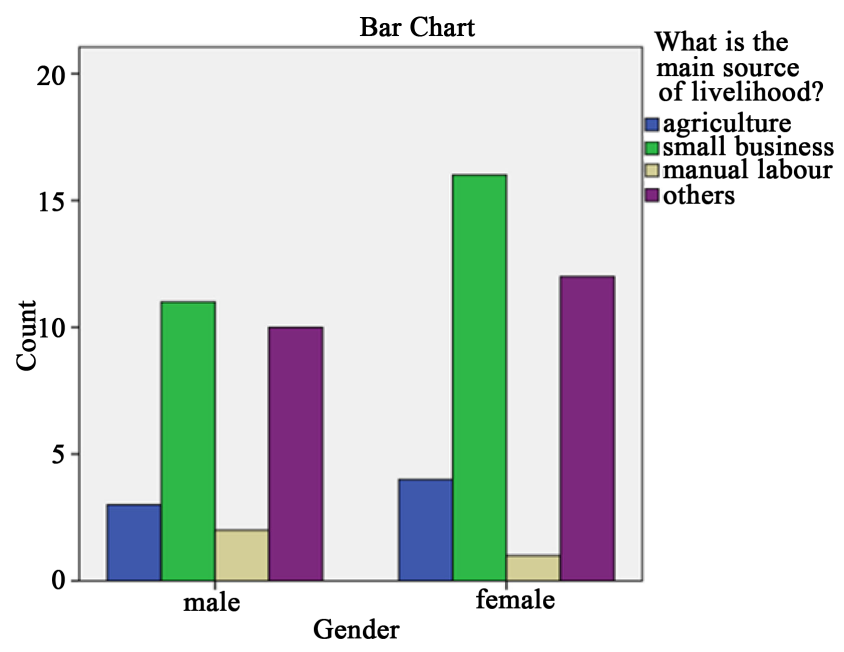

(b)

Figure 6. Sources of livelihood activities. (a) Source of livelihood activities for respondents; (b) Sources of livelihood activities according to respondents' gender. 
is no enough fund to buy a big area and conduct large scale agriculture because their areas where affected by floods.

Hence there is no easy access of means of transport such as buses from where they are staying to the main road results to more financial challenges. Option taken to arrive to main road is to walk a long distance and spend longer time or use motorcycle for transport which needs more money to spend. The fact is they cannot afford using of motorcycle every day because majority they spend money in the process of building good houses on the plotted lands government provided for them. For now, a lot of building constructions are taking place to demolish tent which are in poor condition. Hence there is more job for building constructors and non-permanent job for the other respondent such as carrying of blocks and supply of water in building areas. For retired respondents they only depend on the pension government provide for retired people.

\subsubsection{Overall Loss of Life and Property}

The respondents were asked by how much their property and lives were affected by the flood. The analysis indicated that $80 \%$ of the respondents had some property damage and $10 \%$ had all property damaged. Death cases were reported and the analysis showed that 6 families lost a total of 15 family members that is equivalent to $10 \%$ of families to have lost at least 2 family members, Figure 7 showed the details. Most of respondents lost some of their properties include houses, land, money, livestock, household items such as furniture, electronic devices example television, radio, Iron boxes and so on. Due to this more of social

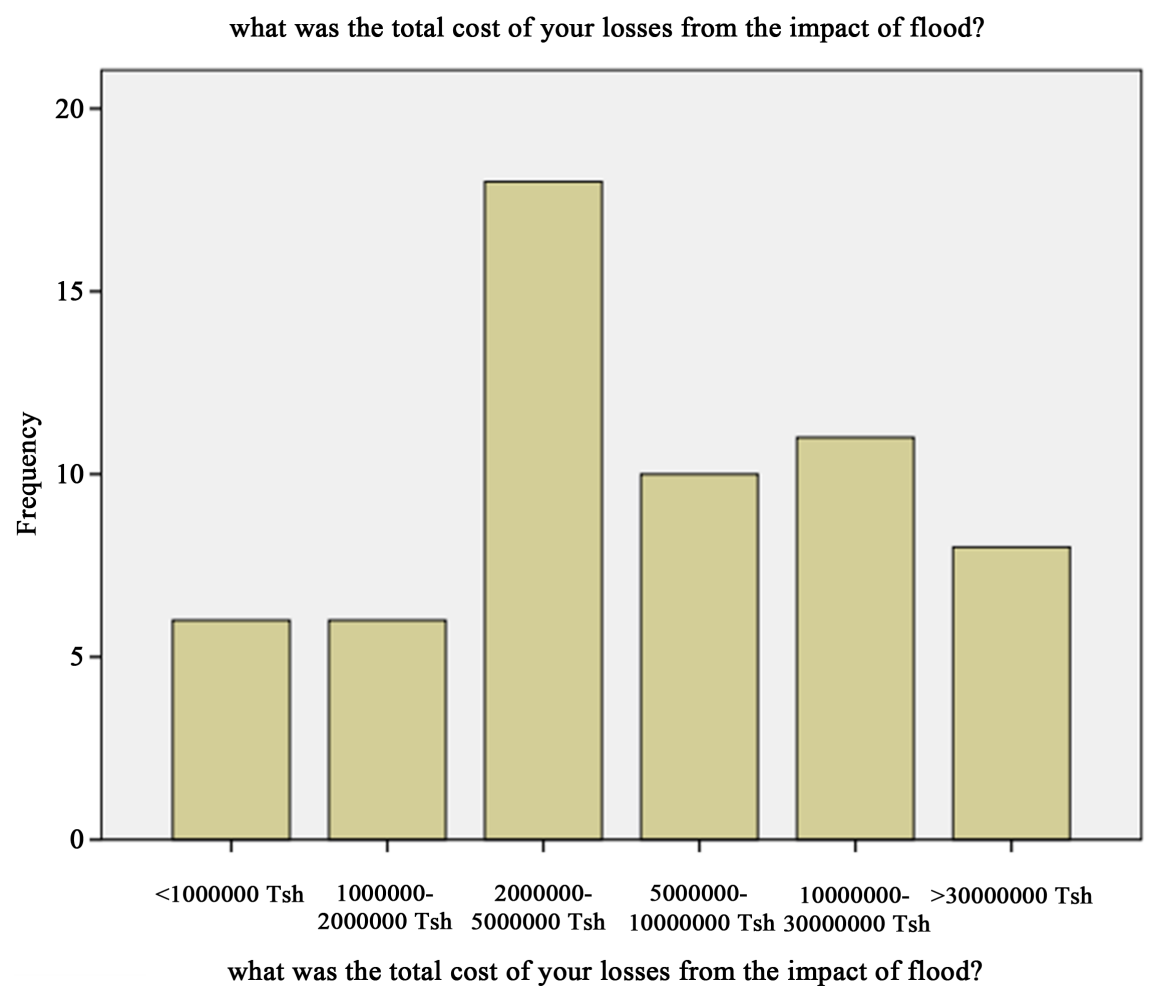

Figure 7. Total cost of the losses from the impact of flood. 
economic impacts caused by the flood were obtained. Also, the study was shown for both of respondents who had nothing left for them, all properties were damaged and those who nothing was damaged, means that they were able to save all their properties on time before the effect of flood took place. Few of respondents lost family members. The respondents were asked to estimate the cost of their property damaged by the flood. The results indicate that the median value-most representatives had property damage worth 7.5 million Tanzania Shillings (TSH) as a result of the flooding event, see Figure 7 above.

Figure 7 shows that more than $50 \%$ of the respondents lost more than two million which is more evidence that they were in good term of living compare to where they are now. Flood caused respondents be poor because no income they depend on the government. The Figures shows other respondents lost above 30 million TSH means that they were already stabilized in term of the basic needs for the family like house and everything which required for a simple home but due to floods all was lost. These had results other who are well good condition of earns income to start building good houses in the plot lands government gave to them. But is worse for others respondent such as elders who cannot do anything than to wait for support from any organization to help them get a better place because they are still on tents which anytime when rain fall down or the presence of strong winds, they will have no place to sleep. Some of the photos taken when questionnaires were administered are shown in Figure 8 below.

Figure 8 below shows the conditions where the respondents were living. They are very poor compared to the life standard of ordinary person. These made majority of respondents feel like not to participate in answering the questionnaire because they need more help of acquiring good houses and nice living condition. Others they were angry at the condition they are living now and they tried to remember what they own before the flood occurred and made them
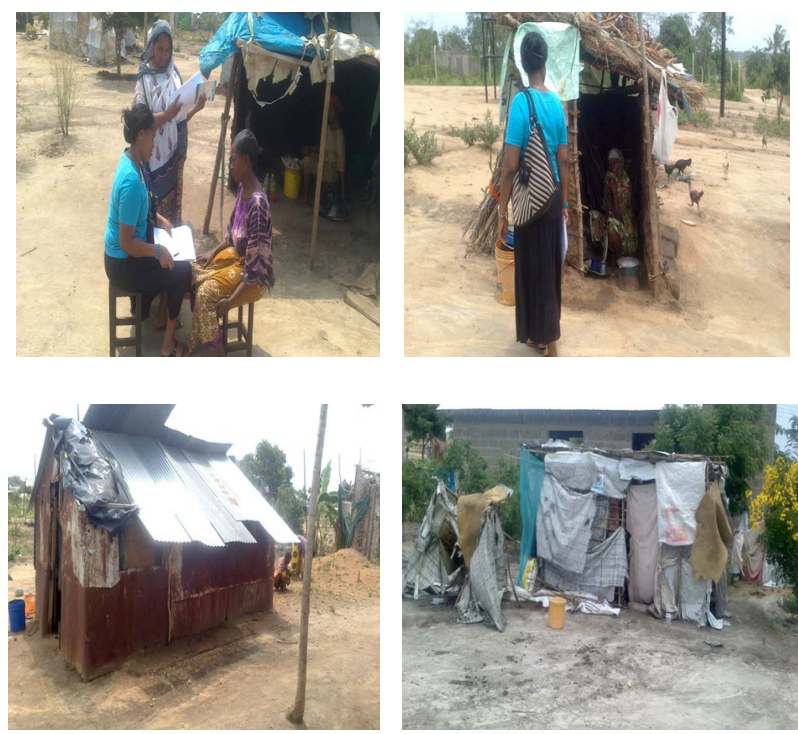

Figure 8. Images of respondents' houses in reallocation area at Mabwepande when questionnaires were taken. 
displaced to Mabwepande areas. Many are still in tents but others they have tried to build muddy houses and corrugated iron sheets but those houses they get old as years goes. In fact, the status where these people are living is worse and they are in the high risk of facing another problem of being like refugees who have nowhere to sleep.

Other social economic effects were obtained from Disaster Management Department of the Prime Minister's Office. They have indicated how much money government spent for relief of affected people from the day flood event occurred to the last stage of provides a plot of land for every household. Even though they are much to be done but still this flood had cost government millions of Tanzanian Shillings (TSH). Table 2 indicates the distribution of money for every support government provides to the affected group.

Table 2. Information of relief government gave for the impacts of flood in Dar es Salaam since December 2011 up to 2013.

\begin{tabular}{|c|c|c|c|c|}
\hline DATE & REGION/DISTRICT & TYPE OF DISASTER & STEP/FUNDS USED FOR RELIEFS & COST \\
\hline $27 / 12 / 2011$ & Dar es Salaam & Floods & $\begin{array}{l}\text { Total amount of TZS } 3,000,000,000 /= \\
\text { spent on Blankets } 3100 \text {; Mattresses } 4658 \text {; } \\
\text { Sheets 5000; Buckets } 1725 \text { given to cater } \\
\text { for affected people. }\end{array}$ & $3,000,000,000 /=$ \\
\hline $11 / 01 / 2012$ & Dar es Salaam & Floods & $\begin{array}{l}\text { Total amount of TZS } 72,962,000 /=\text { was } \\
\text { spent to build a camps to cater } \\
\text { for displaced people due flood at Mabwepande. }\end{array}$ & $72,962,000 /=$ \\
\hline $20 / 01 / 2012$ & Dar es Salaam & Floods & $\begin{array}{l}\text { Total amount of TZS } 76,601,500 /= \\
\text { was spent to build tents to cater } \\
\text { for displaced people due floods at Mabwepande. }\end{array}$ & $79,601,500 /=$ \\
\hline $24 / 01 / 2012$ & Dar es Salaam & Floods & $\begin{array}{l}\text { Total amount of TZS } 41,750,000 /= \\
\text { was spent to repair classes for } \\
\text { students who were affected by floods. }\end{array}$ & $41,750,000 /=$ \\
\hline $25 / 02 / 2012$ & Dar es Salaam & Floods & $\begin{array}{l}\text { Total amount of TZS } 104,970,000 /=\text { spent } \\
\text { for buying desks and building of toilets } \\
\text { in primary and secondary schools } \\
\text { at Mabwepande. }\end{array}$ & $104,970,000 /=$ \\
\hline $16 / 04 / 2012$ & Dar es Salaam & Floods & $\begin{array}{l}\text { Total amount of TZS } 1,080,562,329 /=\text { spent } \\
\text { for providing services and buying items for } \\
\text { the affected people, more repair of classes } \\
\text { at mabwepande, Payment for temporary toilets } \\
\text { in Ubungo maziwa and Mgulani jkt camps, } \\
\text { construction of infrastructures such as } \\
\text { Mabwepande roads, warehouse and expenditure } \\
\text { of the process of saving and migrating the affected } \\
\text { people. Also providing electricity at } \\
\text { Ubungo Maziwa camp. }\end{array}$ & $1,080,562,329 /=$ \\
\hline 19/04/2012 & Dar es Salaam & Floods & $\begin{array}{l}\text { Total amount of TZS } 143,048,000 /= \\
\text { spent for pay for hired toilet } \\
\text { and migration processes. }\end{array}$ & $143,048,000 /=$ \\
\hline $26 / 03 / 2013$ & RAS-Dar es Salaam & $\begin{array}{c}\text { Flood-preparation } \\
\text { of title deeds }\end{array}$ & $\begin{array}{l}\text { Total amount of TZS } 8,917,692.80 /=\text { spent } \\
\text { for preparation of title deeds } \\
\text { for new residence at Mabwepande. }\end{array}$ & $8,917,692.80 /=$ \\
\hline
\end{tabular}

Source: Disaster Management Department (DMD). 
Table 2 above indicated that total amount of Tanzanian shillings of 1,831,811,521.80/= were spent to provide basic needs such as mattresses, bucket, bed sheets, building of tents and toilets, preparing camps, renovation of classes, buying of desks for students, paying of the hired temporary toilets, preparing title deeds for plot of land and the whole process of move people from dangerous area to safer place at Mabwepande. The total amount is equivalent to $1,099,086.91$ USD which is a lot of money. If this disaster did not occur means that the money would be used for other purpose of strengthen economic of the country. But due to that flood government had no option than putting an eye to the affected people in order to reduce the risk of more people lost their life. The impact could have been minimized if proper education on disaster preparedness were given prior to the flood event.

\section{Conclusion and Recommendation}

This study examined the socio-economic impacts of 2011 December flood in Dar es Salaam. This study is important for the disaster preparedness and in development of impact-based flood forecasting models (IBFFM). Results indicate that the flood event of 2011 December was due to heavy rainfall event that occurred from $19^{\text {th }}$ to $22^{\text {nd }}$ December. This rainfall was attributed by the north-easterly wind flows towards the East Africa coastline. The land and ocean temperature contrast, triggered convection process to became enhanced over Dar es Salaam.

The sea surface temperature maps (not presented here) indicated that there was strong warming over the Eastern, North and Northwestern Australia. The prevailed surface Westerly wind pushed warm surface water from topical Pacific Ocean towards western Indian Ocean. This warm surface water spread around western equatorial Indian Ocean coupled with significant warming developed over western Indian Ocean (coast of Dar es Salaam) on 18 - 21 December enhanced more convection along the coastal regions.

Results of socio-economic impacts indicate that the main causes of floods were river overflow due to heavy rainfall and blocked drainage system. Poor infrastructure such as drainage and sewage systems, and ocean surge were identified to be the causes of observed impacts of the December 2011 flood event in Dar es Salaam. Death cases analysis showed that 43 people were reported dead. The flood event damaged properties worth of 7.5 million Tanzania shillings. Furthermore, the Tanzania Government spent a total amount of 1.83 billion Tanzanian shillings to rescue and relocate vulnerable communities that lived-in low-lying areas of Jagwani to high ground areas of Mabwepande in Kinondoni district.

\section{Conflicts of Interest}

The authors declare no conflicts of interest regarding the publication of this paper. 


\section{References}

[1] Stanley, P.G. and Williams, S. (2000) After Disaster: Responding to the Psychological Consequences of Disasters for Children and Young People. New Zealand Council for Educational Research.

[2] Asian, D.R.C. (2002) Living with Risk. A Global Review of Disaster Reduction Initiatives. United Nations.

[3] Parry, M., Canziani, O., Palutikof, J. and Hanson, C. (2011) Key IPCC Conclusions on Climate Change Impacts and Adaptations. In: Brauch, H., et al., Eds., Coping with Global Environmental Change, Disasters and Security, Springer, Berlin, Heidelberg, 1273-1281. https://doi.org/10.1007/978-3-642-17776-7_79

[4] Auld, H. (2008) Disaster Risk Reduction under Current and Changing Climate Conditions. Bulletin of the World Meteorological Organization, 57, 118-125.

[5] Pelling, M. (2011) Adaptation to Climate Change: From Resilience to Transformation. Routledge, Oxon. https://doi.org/10.4324/9780203889046

[6] Poolman, E., Rautenbach, H. and Vogel, C. (2014) Application of Probabilistic Precipitation Forecasts from a Deterministic Model Towards Increasing the Lead-Time of Flash Flood Forecasts in South Africa. Water SA, 40, 729-738. https://doi.org/10.4314/wsa.v40i4.18

[7] Du, W., FitzGerald, G.J., Clark, M. and Hou, X.Y. (2010) Health Impacts of Floods. Prehospital and Disaster Medicine, 25, 265-272. https://doi.org/10.1017/S1049023X00008141

[8] Morrill, E.P. and Becker, J.F. (2018) Defining and Analyzing the Frequency and Severity of Flood Events to Improve Risk Management from a Reinsurance Standpoint. Hydrology and Earth System Sciences, 22, 3761-3775.

https://doi.org/10.5194/hess-22-3761-2018

[9] UN Centre for Regional Development (UNCRD) (2009) Reducing Vulnerability of School Children to Earthquakes: A Project of School Earthquake Safety Initiative (SESI). https://www.preventionweb.net/files/2951_SESIOutcomeallfinal.pdf

[10] Banholzer, S., Kossin, J. and Donner, S. (2014) The Impact of Climate Change on Natural Disasters. In: Singh, A. and Zommers, Z., Eds., Reducing Disaster. Early Warning Systems for Climate Change, Springer, Dordrecht, 21-49. https://doi.org/10.1007/978-94-017-8598-3_2

[11] Thomas, V. and López, R. (2015) Global Increase in Climate-Related Disasters. Asian Development Bank Economics, Working Paper Series No. 466. https://doi.org/10.2139/ssrn.2709331

[12] WMO Statement on the State of the Global Climate (2018) WMO Statement on the State of the Global Climate 2017. https://library.wmo.int/doc_num.php?explnum_id=5789

[13] Boko, M., Niang, I., Nyong, A., Vogel, C., Githeko, A., Medany, M., Osman-Elasha, B., Tabo, R. and Yanda, P. (2007) Africa. In: Parry, M.L., Canziani, O.F., Palutikof, J.P., van der Linden, P.J. and Hanson, C.E., Eds., Climate Change 2007: Impacts, Adaptation and Vulnerability, IPCC, Geneval'

[14] Vizy, E.K. and Cook, K.H. (2012) Mid-Twenty-First-Century Changes in Extreme Events over Northern and Tropical Africa. Journal of Climate, 25, 5748-5767. https://doi.org/10.1175/JCLI-D-11-00693.1

[15] Nyaupane, N., Thakur, B., Kalra, A. and Ahmad, S. (2018) Evaluating Future Flood Scenarios Using CMIP5 Climate Projections. Water, 10, 1866.

https://doi.org/10.3390/w10121866 
[16] Barros, V.R., Field, C.B., Dokke, D.J., Mastrandrea, M.D., Mach, K.J., Bilir, T.E., Girma, B., et al. (2014) Climate Change 2014: Impacts, Adaptation, and Vulnerability-Part B: Regional Aspects-Contribution of Working Group II to the Fifth Assessment Report of the Intergovernmental Panel on Climate Change. Cambridge University Press, Cambridge, 433-467.

[17] Pan-African START Secretariat, International START Secretariat, Tanzania Meteorological Agency and Ardhi University, Tanzania (2011) Urban Poverty and Climate Change in Dar es Salaam, Tanzania: A Case Study, 15-61.

https://start.org/wp-content/uploads/dar-case-study_p1-65_compressed.pdf

[18] Watkiss, P., Downing, T., Dyszynski, J., Pye, S., et al. (2011) The Economics of Climate Change in the United Republic of Tanzania. Report to Development Partners Group and the UK Department for International Development. http://economics-of-cc-in-tanzania.org/images/Final_report_launch_vs_3.pdf

[19] Liwenga, E.T., Kwezi, L. and Afifi, T. (2012) "Where the Rain Falls" Report No 6. Bonn: United Nations University Institute for Environment and Human Security (UNU-EHS), Tanzania.

[20] Hastenrath, S., Nicklis, A. and Greischar, L. (1993) Atmospheric Hydrospheric Mechanisms of Climate Anomalies in the Western Equatorial Indian Ocean. Jour nal of Geophysical Research, 98, 20219-20235. https://doi.org/10.1029/93JC02330

[21] Kapala, A., Born, K. and Flohn, H. (1994) Monsoon Anomaly or an El Niño Event in the Equatorial Indian Ocean? Catastrophic Rains 1961/62 in East Africa and Their Teleconnections. WMO Technical Document, 619, 119-126.

[22] Saji, N.H., Goswami, B.N., Vinayachandran, P.N. and Yamagata, T. (1999) A Dipole Mode in the Tropical Indian Ocean. Nature, 401, 360-363. https://doi.org/10.1038/43854

[23] Anyah, R.O. and Semazzi, F.H. (2006) Climate Variability over the Greater Horn of Africa Based on NCAR AGCM Ensemble. Theoretical and Applied Climatology, 86, 39-62. https://doi.org/10.1007/s00704-005-0203-7

[24] Kebede, A.S. and Nicholls, R.J. (2011) Population and Assets Exposure to Coastal Flooding in Dar es Salaam (Tanzania): Vulnerability to Climate Extremes. Regional Environ Change, 12, 81-94. https://doi.org/10.1007/s10113-011-0239-4

[25] Casmiri, D. (2008) Vulnerability of Dar es Salaam City to Impacts of Climate Change. EPMS, Dar es Salaam, 22 p. 